\title{
3D モデルを用いた 橋梁維持管理システムの開発
}

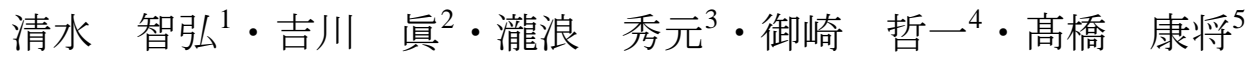 \\ 中山 忠雅 ${ }^{6}$. 内田 修 ${ }^{7}$ - 近藤 健一 8 \\ ${ }^{1}$ 正会員 大阪工業大学大学院 工学研究科（†535-8585 大阪府大阪市旭区大宮五丁目 16-1） \\ E-mail: shimizu@civil.oit.ac.jp \\ 2 正会員 大阪工業大学 工学部（干535-8585 大阪府大阪市旭区大宮五丁目 16-1） \\ E-mail: yoshikawa@civil.oit.ac.jp \\ 3 正会員 西日本旅客鉄道株式会社（一530-8341 大阪府大阪市北区芝田二丁目 4-24） \\ E-mail: hideyuki-takinami@westjr.co.jp \\ 4 正会員 西日本旅客鉄道株式会社（一530-8341 大阪府大阪市北区芝田二丁目 4-24） \\ E-mail: norikazu-misaki@westjr.co.jp \\ 5 正会員 西日本旅客鉄道株式会社（干530-8341 大阪府大阪市北区芝田二丁目 4-24） \\ E-mail:yasumasa-takahashi@westjr.co.jp

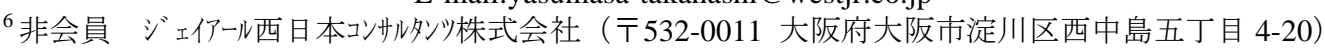 \\ E-mail: nakayama@jrnc.co.jp \\ ${ }^{7}$ 非会員 アジア航測株式会社（†530-6029 大阪府大阪市北区天満橋一丁目 8-30） \\ E-mail: os.uchida@ajiko.co.jp \\ ${ }^{8}$ 正会員 アジア航測株式会社（† 530-6029 大阪府大阪市北区天満橋一丁目 8-30) \\ E-mail: ken.kondo@ajiko.co.jp
}

\begin{abstract}
適切に橋梁構造物を維持管理していくためには, 各種データを一元管理する必要がある. JR 西日本では 通常のメンテナンスは展開図を参照することによって検査, 補修が行われている. しかし，変状もしくは 補修の位置や形状を記録する維持管理用の展開図は，寸法のない模式図である。さらに，検査と工事で共 通に使用できず，時系列管理を行いにくいという課題がある。そこで，著者らは，3D モデルを活用した橋 梁維持管理システムを開発した。 また, 点検や修理を管理するための展開図を簡単に作成できるシステムを 開発した。 さらに，本システムの有効性を確認した。
\end{abstract}

Key Words: construction information modeling, system development, maintenance cycle management, 3D model and stereo photo

\section{1. はじめに}

機械設計・製造分野では 1970 年代から CAD(Computer Aided Design) と CAM(Computer Aided Manufacturing), CAE(Computer Aided Engineering) を統合化した CIM(Computer Integrated Manufacturing)が推進され，その 中で 3D-CAD も利活用されていった. その後, 建築分野 でも，CIM(Computer Integrated Manufacturing)などの情報 化技術によって建築生産の合理化に取り組んできた ${ }^{1)}$. さらに，BIM(Building Information Modeling)が普及してき ており，意匠や構造、設備などの設計から FM(Facility Management)などの維持管理まで幅広く利活用されてい る. 一方，土木インフラ分野に目を転じてみると 2008 年に策定された「CALS/ECアクションプラン」の中で情 報通信技術 (以後, ICT : Information and Communication Technology）を活用した建設生産システムの構築を目指
して 3D モデルの利活用が押し進められたものの十分に 浸透せず, 今もなお2Dモデルの利用が多い状況にある. 実務の現場での電子納品，情報化施工，情報共有システ ムなど CALSE/EC によって一定の成果が得られたもの の，一方で CALS/EC が目指してきた調査〜計画〜設計 〜積算〜施工〜維持管理までの建設プロセスを一貫して 情報化させるためのシステム構築については実現には至 らず課題として残っていた ${ }^{2)}$.

そのような中, 2012 年になると土木版 BIM と呼ばれ る CIM(Construction Information Modeling)が国交省から提 唱された ${ }^{334)}$. CIM とは，施設や構造物の 3D の形状情報 にくわえ属性情報(材料・部材の仕様, 性能, コストなど の情報)を併せもつ建設情報モデルのことである. 建設プ ロセス全体で関連情報を一元的に共有・活用させること により生産性の向上を図ることを目的としており，これ はBIM の概念を参照している(図-1). 


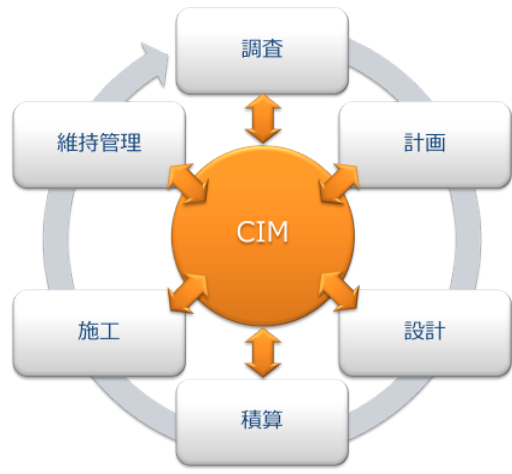

図-1 CIMの概念

Computer Integrated Manufacturing は形状のみで，各々 の形状に意味は持たせていない 3D モデルを扱うことが 主流であるのに対し，Construction Information Modeling は，形状にくわえ材料・部材の仕様，性能，数量，コス トなどの属性情報(意味情報)を持たせた $3 \mathrm{D}$ モデルであ るといえる。

\section{2. 研究の目的}

BIM や CIM は次元(軸)を「評価軸」として捉えている. 立体的な構造物を示す $3 \mathrm{D}$ にくわえ，「時間」軸を考慮し た 4D や「コスト」軸を考慮した 5D を含めた活用の検討 が進められている．さらには，「維持管理」軸を考慮した 6D が出現し始めており 5) 6)わが国においても少子高齢 化，技術の伝承，施設の更新等の社会資本を取り巻く環 境が変化してきている中で BIM やCIM を活用した「維 持管理の効率化・高度化」が重要となっていくと考えて いる，そこで，本研究では維持管理に焦点を当てた.

わが国では，高度経済成長期に大量の社会資本（イン フラ）が整備・蓄積されてきた。これらの社会資本スト ックは, 建設後すでに 30〜 50 年の期間を経過しているこ とから，今後，急速に老朽化が進行していくと想定され る.このような状況を鑑みれば社会資本における適切か つ効率的な管理と評価技術の高度化が一層求められる状 況にある.これまでの社会資本における維持管理につい ては，機能的な信頼度が直ちに大きく損なわれるような 事象が少なかったことから，損傷が発生してから修繥な どの対処をする「事後的管理」が行われていた.しかし， 今後，高龄化したストック（社会資本）が増大していく と致命的な損傷が発生する可能性が飛躍的に高まる。 そ のような中，事後的な対処で万全を期すことは困難であ り，結果として安全性が大きく損なわれる恐れがある. 既存の構造物を効率的かつ適切に維持・管理・更新して いくためには，早期に修復が必要な箇所を発見すること により，構造物の長寿命化を図る「予防保全的管理」へ の転換が必要である.
予防保全的管理として構造物の機能を維持していく ためには，検査〜計画〜工事という流れの中で，各種デ ータを蓄積するとともに，これらを常に最新のデータに 更新しておくことを継続的に実施していく必要がある.

建設プロセスの各段階におけるさまざまなリスクを より上流で管理する「フロントローディング」が CIM の 目指すべき方向として掲げられている ${ }^{7)}$. そのため, 計 画や設計段階における CIM の活用について積極的に取 り組まれている ${ }^{8)}$. 計画や設計段階で施工や維持管理を 見据えてどこまでのデータを作成するかを見極めること は CIM が普及するうえで欠かせない．しかしながら，施 工や維持管理を考えて作成したつもりのデータが，実際 の施工や維持管理の場面で役に立たなければ，設計の手 間が無駄に増えてしまうだけになる。すなおち「フロン トローディング」を効果的に進めていくうえでも下流の 施工や維持管理において 3D モデルがどうあるべきかと いったあり方についても併せて議論し, 3D モデルの重要 性について「ボトムアップ」していくことも CIM を推進 していくうえで重要であると考えている.

以上の点を踏まえ本研究では，予防保全的管理を目指 した維持管理を支援していくための適切かつ効率的な手 法を開発するとともに, 今後の CIM を活用した建設プロ セスの重要性について維持管理の観点から考察する.

\section{3. 研究の方法}

わが国における鉄道構造物は，橋梁（1m 以上）が 102,293 施設，トンネルは 4,737 施設に上る. 鉄道は自動 車（マイカー）の普及以前に整備された路線も多く，平 均経年数は橋梁が 56 年，トンネルが 62 年で, 100 年以 上にわたり継続使用される橋梁やトンネルは15,000施設 を超えているといわれている9).

そのような状況のもと，国交省は 2007 年に鉄道施設 の検査方法や検査周期といったメンテナンスに関する技 術基準となる「維持管理標準」を施行し ${ }^{10)}$ ，2013 年にな るとその検査の周期や方法等について妥当性を検証し， 必要な対応を検討するなどの見直しが進められている ${ }^{9)}$. 現在は，すべての鉄道事業者が共通の体系でメンテナン スに取り組んでおり, JR 西日本においても土木構造物が 供用期間を通じてその要求性能を満足するよう，定期的 に検査を行い，必要に応じて措置を講じている.

その中で，2D の図面(展開図)を参照しながら検査〜計 画〜工事までの維持管理業務を行っている（図-2の一方 向矢印部分).この方法は, 熟練した技術者のみで作業を 進めていくのであれば有効である，しかしながら，実際 は一連の維持管理サイクルの中に，さまざまな関係者が 多数存在する. その場合, 2D の情報のみで維持管理に関 
わる内容などを十分に理解し合うことは難しい. 最悪の ケースでは，関係者間で十分な合意形成ができないまま 作業を進めてしまい，その結果，作業の手戻りや作業期 間の延長といった問題が発生してしまうことも考えられ なくはない. すなわち, 2D のみの管理では, 適切な維持 管理が難しく生産性を低下させてしまう可能性がある.

適切な維持管理を行うためには，関係者間で検査や工 事段階の知識を簡単に共有することが重要であり，視覚 的表現に優れた 3D データの利用が有効であると考えら れる.とくに構造が複雑であればより効果的であると考 えられるため, 本研究では, 対象構造物を橋梁に選定し た. また, JR 西日本では, 適切な維持管理を行うために, 橋梁諸元, 検査データ, 補修履歴等のデータベース化を 行い, 検査計画, 補修計画を支援や検査・補修データから アセットマネジメントを行うための橋梁保守管理システ ム(以後, BRAMS : Bridge Analysis and Maintenance System) を 2002 年に構築している ${ }^{11)}$. しかし，構築後 10 年が経 過し，さまざまな課題・改善要望が挙げられている. 具 体的には，現場で検査・工事してきた結果を BRAMS に 手動で入力する必要があり(紙ベースから複製する必要 がある)手間がかかるといった課題が発生していた。く えて，展開図の使用性の向上がある，現状の展開図にお ける課題を以下に示す.

(1) 現場スケッチによる展開図作成, 写真整理, 数量算 出などのデータ管理作業に多大な労力を要する.

(2) 展開図は検査と工事で異なるフォーマットにて作 成されている場合があり, データの相互利用ができ ていないケースがある。

そこで，本研究では 3D 橋梁モデルを活用して一連の 維持管理サイクルの中で展開図を中心とした正確な時系 列管理ができる環境の構築や各種データの一元管理，お よび作業員による記録作業の効率化を目指したシステム の構築を行った。 具体的には, JR 西日本における山陽新 幹線の高架橋と桁橋を対象とし 3D モデルから寸法を持 った展開図を作成し, 撮影写真から変状・補修数量を算 定する手法を開発した。

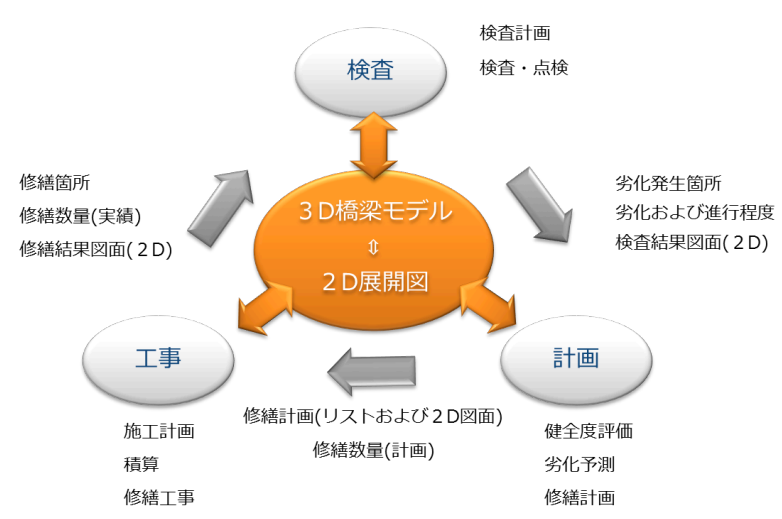

図-2 従来の維持管理の流れと本手法の比較

\section{3D 情報モデルを用いた維持管理システム}

橋梁展開図作成・管理システム (以後, BBMAPS : Bridge

Base Map Plot System）は2つの機能で構成される.

1 つ目は 3D モデルから寸法を持った展開図を簡易に 作成する機能 (橋梁展開図作成システム), 2 つ目は 3D モデルを活用した撮影写真の効率的な管理手法と撮影写 真から変状・補修箇所の位置や数量を算定する機能（変 状・補修管理システム) である. 詳細について後述する.

\section{(1) 3D モデルの構築}

\section{a) 構造パラメータによる 3D モデルの構築}

今後, 老朽化した構造物が急速に増大していくことが 予想される中で適切に維持管理を行っていくためには, いかに効率よく3D モデルを作成することができるかが 重要となってくる. 一般的な 3DCAD ソフトを利用し, 対象となる橋梁を 1 つずつモデリングしていくことは, 費用的にも時間的にも困難であると考え, 本システムで は構造パラメータを入力するだけで簡易的な 3D モデル が作成される仕組みを構築した．まず，橋梁構造別の橋 梁3Dモデルから対象橋梁と同タイプの3Dモデルを選択 すると標準的なモデルが自動的に構築される. なお，本 システムでは, ラーメン高架橋, コンクリート単 $\mathrm{T}$ 桁(ゲ ルバー桁), コンクリート単版枌 (スラブ枌), PC 単 T 型桁, PC 単 I 型桁, 箱型桁から選択寸ることができる. 次いで，部材寸法が分かる図面などを参照して構造パラ メータに部材寸法を入力することで詳細な橋梁 3D モデ ルを構築することができる，具体的には，端部構造形式 (張ね出し，ゲルバー，背割など）と端部寸法や径間数, 柱本数・寸法・間隔, 縦梁・横梁 - 中層梁の寸法 (中層 梁については無も可能), 枌断面寸法, 付帯構造物 (高欄, 防音壁, 電柱支持梁) の種別とその寸法などが構造パラメ 一タとして入力することができる. 対象となる山陽新幹 線の橋梁構造は，類似している場合が多い。このように 類似性の高い構造物については同手法が有効である.

\section{b) ステレオ撮影装置}

部材寸法入力に必要となる図面等がない，読み取りに くいなどの場合がある，その場合は，現場での測量作業 が必要となる．構造物に近接できる場合は，メジャーに よる測定など手動で計測する方法が適用できるが，橋梁 のような巨大な構造物の場合において近接して測定でき ない場合も多い. また, 高所作業車での作業が必要とな るケースもあるため接触の測定には安全面にも課題が残 る.一方，遠隔にて非接触による測定手法がある。非接 触の測定方法としては，TS(トータルステーション)や地 上レーザによる方法がある。これらは，非常に高い測定 精度が得られるものの設置位置の正確な座標算出が必要 となる.また，複数の地点からの観測や測定データを必 
要とし，その解析にも時間がかかるなどの課題がある. 維持管理において現場での作業をいかに簡略化するかが 重要となる. そこで，コンクリート橋梁の柱や梁などの 寸法をターゲット不要で，簡易かつ精度良く計測を行う ことを目的に，ステレオ計測を活用した撮影装置（図-3） の開発を行った. ここで，ステレオ三次元計測の原理を 図-4 に示す. 焦点距離 $f$ のカメラで，基線長 $B$ の間隔で 被写体 $\mathrm{P}$ を写し, その像点 $\mathrm{p}_{1}\left(x_{1}, y_{1}\right), \mathrm{p}_{2}\left(x_{2}, y_{2}\right)$ が得ら れたとする. 2 台のカメラのレンズ中心を結ぶ方向を $\mathrm{X}$ 軸とし, 左側のカメラのレンズ中心を原点となるように 三次元座標系を設定する. 2 本の空間直線（光束）の式 から被写体 $\mathrm{P}$ の三次元座標 $(X, Y, Z)$ は次の式で与えら れる.

$$
\begin{aligned}
& X=\frac{x_{1}}{x_{1}-x_{2}} B \\
& Y=\frac{y_{1}}{x_{1}-x_{2}} B \\
& Z=\frac{-f}{x_{1}-x_{2}} B
\end{aligned}
$$

本装置は，現場での携帯性，操作性，かつ対象橋梁の 測定精度確保という相反する条件を満足させるため, 基 線長, 撮影距離, 撮影角度, 及び測定部材寸法をパラメ 一タとして，寸法測定の測定誤差に関してシミュレーシ ヨンを実施し, カメラ性能，基線長などを決定した。

装置の測定精度は，白図の展開図作成を目的とするこ とから, mm 単位の高精度ではなく, 部材寸法の $5 \%$ 以 内という測定精度を目標とし, 装置の携帯性を重視した。

本ステレオ撮影装置を用いて，精度検証を行った結果 を図-5 に示す. 図-5 のプロットは測定寸法 L/実寸法 Lo の值を示している.標準偏差は 2.3\%であり, 目標精度 $5 \%$ を確保できる事が確認できた. 本ステレオ撮影装置は, 固定基線方式を採用しているため, 測定対象物に一切の ターゲット貼付が不要であり，現地での作業は撮影のみ である. また, 装置全体の重量は $1.5 \mathrm{~kg}$ 以下であるため, 作業者の撮影作業の負担も小さい.

\section{c) バッチ処理による橋梁 3D モデルの一括構築}

さらに効率的に橋梁 3D モデルを作成するためにバッ チ処理によって一括で作成される仕組みを構築した。 具 体的には, 複数橋梁に対して構造パラメータ入力に必要 な橋梁諸元(橋梁名, 構造形式名, 構造種別, 柱本数や間 隔, サイズおよび高さ，ゲルバー，背割，はね出しの端 部種別と端部寸法など)が入力された csvファイルを読み 込むことで標準的な橋梁 3D モデルを一括で作成するこ とができる．本処理によってモデル作成のさらなる省力 化につながった。

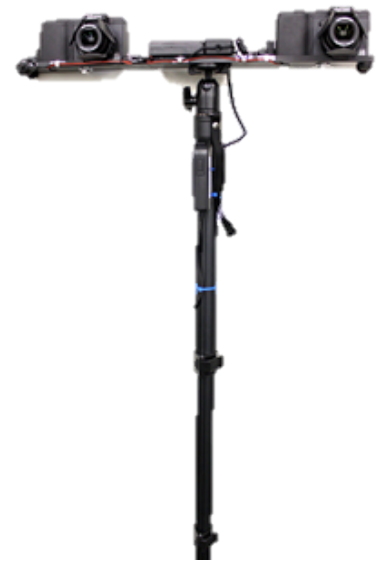

図-3 ステレオ撮影装置

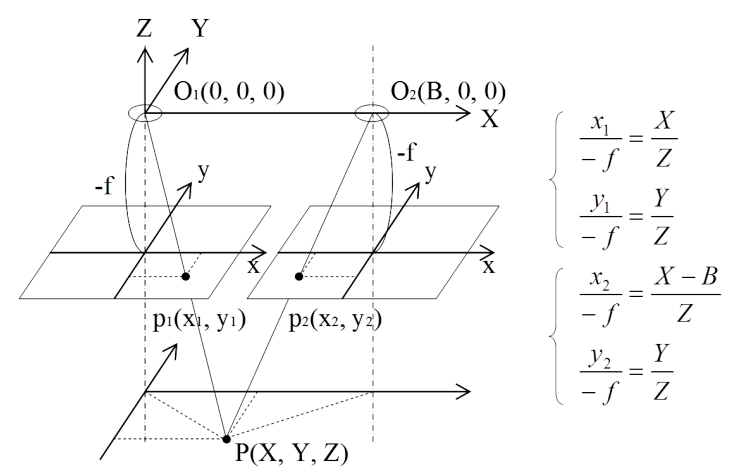

図-4 ステレオ 3 次元計測の原理

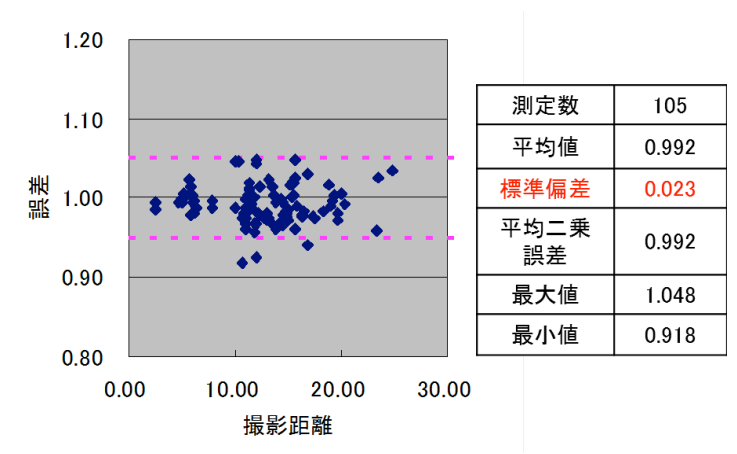

図-5 ステレオ撮影装置の計測結果

\section{(2) 写真管理}

維持管理業務では，図面管理と併せて現場で撮影した 写真も管理している。一度の現場作業で膨大な写真を撮 影するために撮影写真の管理が煩雑となってしまい, 過 去のデータを検索することが困難な状況になることも少 なくない. 構造物の測定や点検においては，撮影写真が どの部位をどの位置から撮影したものであるかを管理で きなければその写真は効力を持たない. しかしながら， 撮影した構造物の部位と撮影位置を対応づけて管理する ことは非常に面倒な作業であり，それぞれの撮影写真の 位置関係を把握することはさらに困難であった。

そこで本システムでは, 構造物と撮影写真の位置関係 
を視覚的に把握できるようにするため, 3D モデル空間上 に撮影した写真が配置される仕組みを構築した．具体的 には, 3D モデルと撮影写真の両者に対して, 部材端部な どの特徵的な点を最低 4 点(最高 8 点)指示することで, 撮影したカメラ情報をもとに撮影位置と撮影方向が正確 に求められ，3D 空間上に正確に配置することができる

(図-6).この際，レンズひずみなどを除去することによ り , 3D モデルと撮影写真をマッチングさせることができ る（図-7）。これにより，別日あるいは別の作業者が撮影 した写真であっても写真同士の位置関係が容易に把握・ 管理できるようになった．本システムにより現場で撮影 してきた写真が一元的に管理できるだけでなく，撮影し てきた写真を効果的に活用できる仕組みが構築できた (図-8).

\section{（3）検査·工事履歴管理}

「予防保全管理」を実現するためには，構造物の腐食 や劣化などの経年変化をいち早く把握し，さらには，最 も費用対効果の高い修縜計画を策定し，検査・工事の内 容を時系列でわかりや寸く把握しておく必要がある。ま た，優先的に修繒すべき箇所を把握するためには，その 進行具合（健全度）を的確に評価する必要がある。その ためには，検査・工事箇所の位置や数量を正確に記録し なければならない.

そこで，本システムでは，前節で述べた 3D 空間上に 配置させた撮影写真を活用した記録方法を採用した. 3D 空間上に配置された撮影写真は，写真の撮影位置および 撮影角度が求められているため, 写真上の点 $\mathrm{p}$ が示寸 $3 \mathrm{D}$ 空間上の視線ベクトルが一義的に決定される。その視線 ベクトルと 3D モデルが交差する面上の点 $\mathrm{P}$ を計算する ことで, 変状・修繥図形の XYZ 座標值が計算される（図 -9). 寸なわち, 変状や補修箇所を単写真で撮影し, 写真 上の変状(目視調査であれば目で見える範囲, 近接調査で あればチョーキング範囲)や補修箇所を図形でなぞるこ とで，3D モデルに正確な位置および形状や数量(長さや 面積)が反映される（図-10）。また，個別の検查・工事図 形に ID を持たせることにより，経年的な変状の進行や 工事時による修繥履歴も把握することが可能となった (図-11) .

2D 図面による構造物の腐食や劣化, あるいは修繥履歴 などを管理していく場合，実物の橋梁構造物の 3D 空間 構成をイメージすることが難しいだけでなく, 経年変化 を把握しにくいという問題が発生していた. また, 検査・ 工事箇所の位置および数量を正確かつ安全に測定するこ とは容易でない，たとえば，検査箇所の位置および数量 を測定するためには，高所作業車などにより対象箇所に 接近し,スケールを用いて測定することとなる.しかし， このような測定方法は準備作業が多く作業負担が大きい.
さらには，高所作業となるため安全性の点においても課 題が残る.

また，ズームカメラによる点検作業を行うことも可能 であるが，この場合，点検箇所の位置および数量の測定 に正確性を欠く．さらに，その結果を別途手動により $2 \mathrm{D}$ 図面（展開図など）に記載するため, 記載自体が模式図 的なものになってしまう.

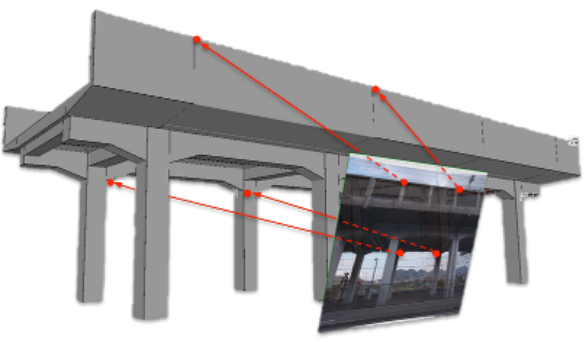

図-6 写真マッチング手法

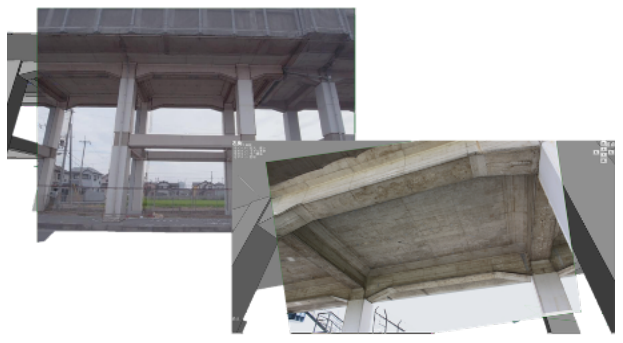

図-7 写真マッチング結果

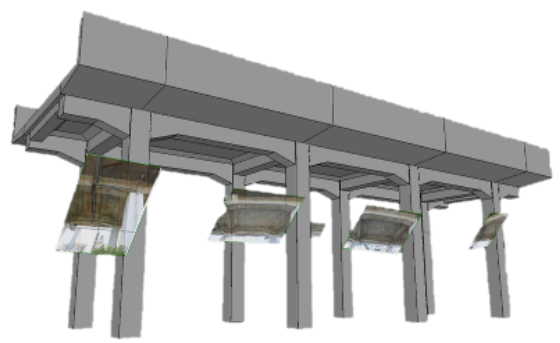

図-8３D空間上への写真配置

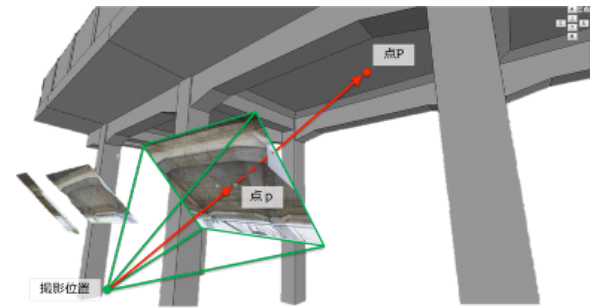

図-9 3Dモデルと写真の対応関係

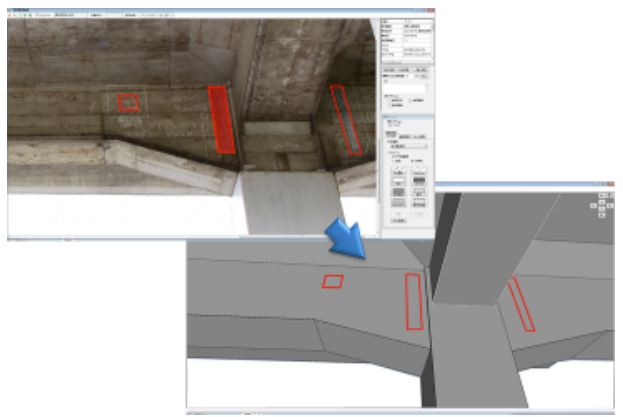

図-10 変状・修繥図形入力結果 
本システムを活用すれば，3Dモデルを用いて検査・工 事箇所が視覚的かつ容易に把握することができる。さら に，正確で安全な点検位置・数量（長さや面積）の測定 が可能となる.

\section{（4） 2D 図面の作成・出力}

橋梁のような構造物の場合，その構造が多種であり複 雑なため，個々の構造に対して図面を作成することに多 くの労力がかかっていた．また，図面自体の精度につい ても十分に確保されない場合もある。本システムによれ ば，構造パラメータを変更するだけで 3D モデルが作成 され，その形状を反映した 2D 図面（展開図）が自動的 に出力できる機能を有しているため, どんな複雑な構造 でも瞬時にかつ高精度に出力することが可能となる。さ らには，構造の形状だけではなく, 3D モデルに表現され ている点検・補修箇所についても位置および形状や数量 も正確に出力することができる(図-12).

本来, 3D モデルさえあれば検査・工事の記録を参照す るうえで十分である。しかしながらユーザの利便性を低 下させないためにも現状の管理の仕方をなるべく変えな いことも考慮する必要がある，そのため，すべて 3D モ デルで管理することに置き換えてしまうよりも，見慣れ た 2D 展開図に出力できるようにしておくことは，必要 であると考えている.

\section{ICT を活用した橋梁検査ツール}

CIM を推進していくうえで 3D データモデルの導入・ 活用にくわえ ICT を活用し，業務プロセスにおける各情 報の一元化や業務改善による効率向上を図ることが重要 である．前章までは内業に重点をおいた開発であるが，

BBMAPS と連携し, 現地撮影および検査業務の外業を支 援，ならびに現場作業から事務所作業までのスムーズな データの引渡しを目的として， ICT を活用した橋梁検査 ツールを開発した。

基本的な考え方としては，現在行われている検査の外 業作業方法（紙で打ち出した展開図を持参し，メモ（撮 影写真番号，撮影位置，変状状況，変状箇所位置など） を作成する方法）にとって代わるものである.

\section{(1) 携帯端末の選定}

携帯端末については，現場作業で支障なく使用できる よう, 操作性, 可搬性の良いタブレット端末とした。

OS については，開発言語，配布（審査），流通アプリ ケーション数, 国内販売シェアの観点から Android とし た.

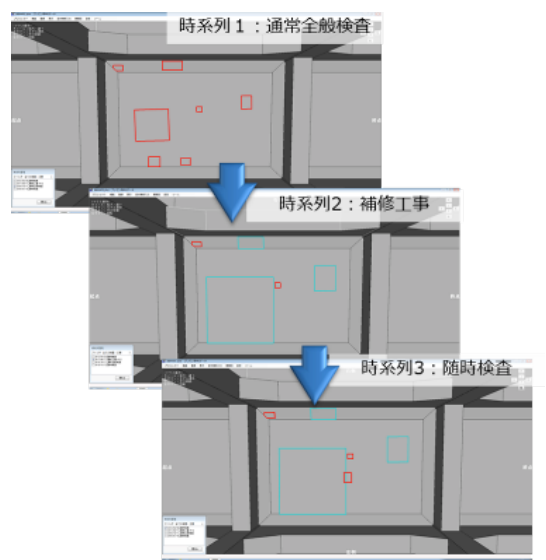

図-11 時系列管理(赤色線 : 変状 水色線 : 補修)

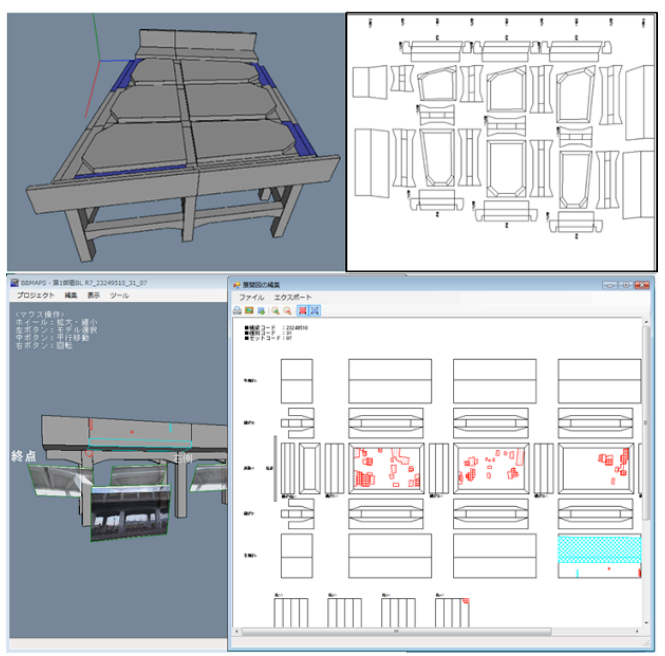

図-12 2D図面(展開図)の出力

\section{(2) 写真画像転送方法}

タブレット端末内蔵のカメラで撮影する場合は，本検 討の必要はない.ただし, タブレット端末内蔵のカメラ は，検査時の要求性能（解像度，ズーム機能，フラッシ ユ機能など）を満たすことが難しいため，現状通りデジ タルカメラで撮影することとした。その際に，デジタル カメラからタブレット端末に撮影写真を転送することが 必要となるため，その転送方法について検討を行った。

転送方式については，現場での利便性から，有線では なく無線方式とした．無線通信方式の中でも，撮影した 写真データが数秒の時間差で直接タブレット端末に自動 的に転送され, 利便性に優れる Wi-Fi 通信 Eye-Fi 方式を 選定した。

\section{(3) 橋梁検査ツール}

現在行われている検査の外業作業方法の代用とする ため, タブレット端末を活用した撮影位置, 変状補修位 置および各種メモの記録手法に関する開発を行った．以 下にその概要を示す.

あらかじめ対象高架橋の3DモデルをBBMAPS で作成 し，橋梁情報や展開図，過去の検査・補修情報などを属性 
情報として付与した状態で SD メモリーカードもしくは USB ケーブルにより, タブレット端末の橋梁検査ツール に出力する.

入力されたタブレット端末を現場に持参し，デジタル カメラに Wi-Fi 通信 Eye-Fi 方式の SD モリーカードを セットし，変状箇所などを撮影する．撮影した写真デー タは自動でタブレット端末に転送される。転送された写 真の撮影位置については，取り込まれた画像をタッチで 選択し，撮影点と撮影方向を撮影計画図上でドラッグす ることにより記録される. BBMAPS に出力する際には, この情報がそのまま引き継がれ，簡易に写真が配置され る（図-13）。この作業を行うことで，現場での紙による 撮影位置や撮影対象箇所の記録や事務所に持ち帰った後 の確認・整理を行わなくてもよくなる.

検査記録方法については，選択した写真上で変状箇所 を指でマーキングする.マーキングした図形には, 変状, 部位, 判定などを入力することができる. BBMAPS に出 力する際には，撮影位置と同様，情報が引き継がれ，メ モ機能として登録される（図-14）。この作業を行うこと で，記録として写真のどの位置の，どのような変状を撮 影したかなどの確認作業を行わなくてもよくなる.

\section{6. 検証}

\section{(1) 作業時間}

検査〜計画〜工事の一連の維持管理サイクルのうち, 検査の工程に対して，現地作業を試行し，本システムを 用いた新作業方法と従来の検査法の作業時間について検 証を行った. 具体的には, 同じ 3 径間ラーメン高架橋((計 2 セット)に対して実際に内業・外業にかかった時間をス トップウォッチにて測定し， 1 セット当たりの平均作業 人工の算出 $(1$ 人当たりの作業時間 $\times$ 作業人数 $)$ を行った 表-1). なお，検査の方法は眺望目視である. その結果, 従来方法に比べ検査工程では約 $1 / 4$ 程度への時間短縮と 作業人数の削減が可能であることがわかった（図-15).

従来法の検査は，外業では 3 人/組(写真撮影者, 眺望 目視での変状箇所寸法計測員, 変状メモ作成等記録員) で検査が行われるのに対し，本手法では外業は 2 人/組 (写真撮影者，撮影箇所指示員)，内業は準備(3D モデル 作成), 写真取込 - 変換, 写真貼付, 変状図形入力, 展開 図・数量出力の作業を 1 人のみで行える.このように本 システムでは外業は写真を撮影するのみでよく, さらに, 内業についても従来法では個別に写真の整理や展開図, 記録簿，変状数量表の作成を行っていたが，本システム では写真に写った点検箇所をなぞるだけで自動的に管 理・出力されるため作業時間の短縮につながったと考え ている.

\section{（2）測定精度}

つぎに，測定精度について比較検討を行った．個別の 工事箇所（断面修復箇所）を抜粋し，(1)従来法面積（工 事写真からの定規読取值) と(2)本システム面積の誤差 (1) 一(2) を算出し，測定精度の評価を行った．検証箇所は 63 箇所, 平均断面修復面積は $1.612 \mathrm{~m}^{2} /$ 箇所(0.11\%)であ り, 結果としては, 平均誤差が-0.002 m², 標準偏差が 0.010 $\mathrm{m}^{2}$ であった. また, 図-16 に示す通り䛊差の平均值が 0 中 心にあること，誤差分布が正規分布に近い分布にあるこ とから本システムの測定值の信頼性は高く現場作業に十 分適用できる精度結果が得られた。

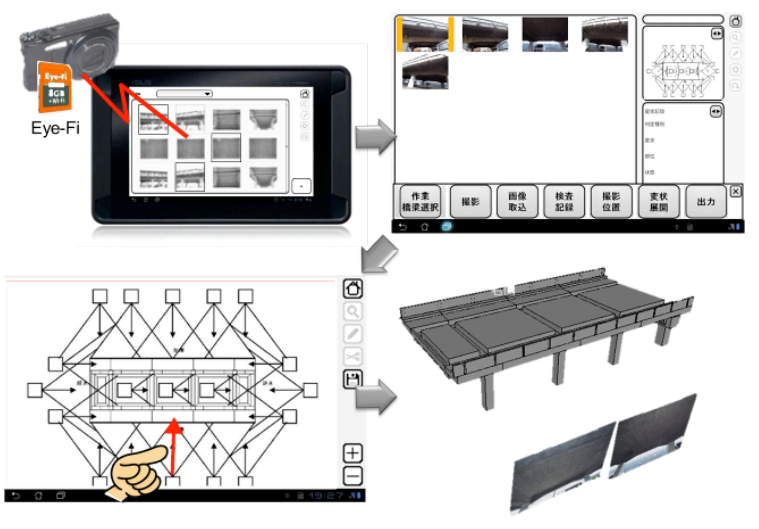

図-13 撮影位置記録

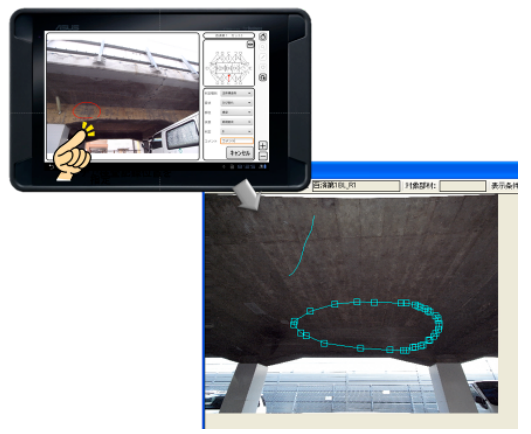

図-14 変状箇所記録

表-1 検証高架橋状況

\begin{tabular}{c|c|l}
\hline 業務 & 構造物名 & \multicolumn{1}{|c}{ 状 況 } \\
\hline \hline \multirow{3}{*}{ 検査 } & $\mathrm{R} 1$ & $\begin{array}{l}\text { 鉄筋露出63箇所 } \\
\left.\text { ひびわ平均面積 } 0.030 \mathrm{~m}^{2}\right)\end{array}$ \\
\cline { 2 - 4 } & $\mathrm{R} 2$ & 鉄筋露出50箇所 (平均面積 $\left.0.076 \mathrm{~m}^{2}\right)$ \\
\hline
\end{tabular}

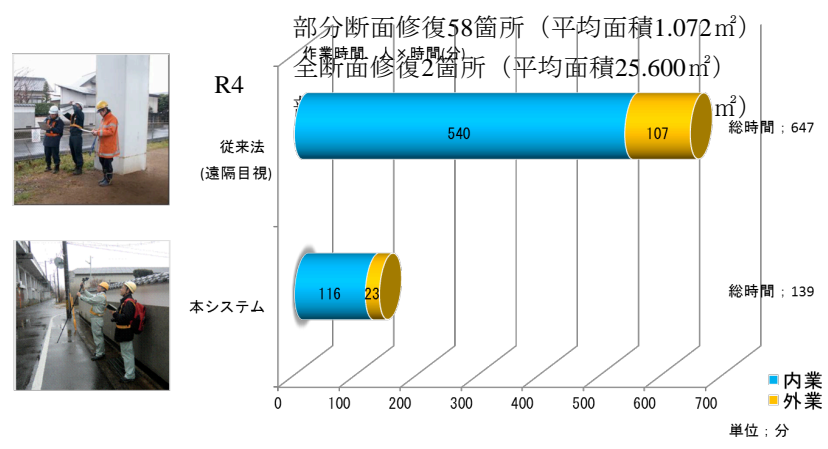

図-15 従来法との作業時間比較 
今後は，検査，工事の断片的な検証ではなく，PDCA を意識した検査 計画 工事の一連の維持管理業務の中 で本システムを用いて検証を行い，使い勝手等の改善を していくつもりである.

\section{7. おわりに}

本研究は，単に個別の業務で便利な情報モデルを作成 すること(Construction Information Modeling)ではなく，多 くの関係者間で3D 情報モデルを通じて維持管理の仕組 み自体を効率化・高度化すること(Construction Information Management)を目指している. 本システムを利用するこ とにより, 3D 情報モデルをプラットフォームとして関係 者間での撮影位置や検査・工事履歴, 図面などの共有化・ 一元管理が可能となった. 従来の方法では，2D 図面（展 開図）以外にも写真整理，数量算出などデー夕管理に多 大な労力を要していたが，本システムを利用することに より，時間の短縮を図れる．また，検査・工事箇所の正 確な位置関係や寸法が経年的に管理できるため，各関係 者が連携して「予防保全管理」に向けたアセットマネジ メントが実現可能であり，CIM(Construction Information Management）としての一定の成果が得られたものと考え ている.

CIM の活用について関連技術，とくにセンシング技術 との連携の重要性を指摘している ${ }^{3)}$ 。この点について本 システムでは写真測量技術との連携というかたちで有意 性を示すことができた. くわえて，ステレオ計測機器の 開発では，CIM 導入における重要な要素としている「維 持管理を考慮した計測機器の組み込み等による高度化」, タブレット端末による現場支援ツールの開発は「ICT を 活用した業務の効率化」につながるものと考えている. このように CIM の活用が維持管理の場面でもさまざま な効果が得られた。

現状システムの課題として, 3D モデルと撮影写真の対 応点を指示する「撮影写真の 3D 空間配置」の作業と写 真をなぞることで描画される「検査・工事図形の入力」 作業が手作業であるために内業の大部分を占める作業と なっている (図-17).これらの課題に対しては，3Dレー ザースキャナーや画像処理による特徴点や図形の自動抽 出などを導入することによってさらなる「維持管理の効 率化・高度化」を進めていくことができると考えている.

今後は，鉄道橋梁以外にもトンネルや法面など他の土 木構造物や施設，設備といった建築物への適用も可能と なる汎用性の高いシステムを目指していくことで CIM と BIM が一体となった 3D モデルへの活用検証を進めて いきたい.

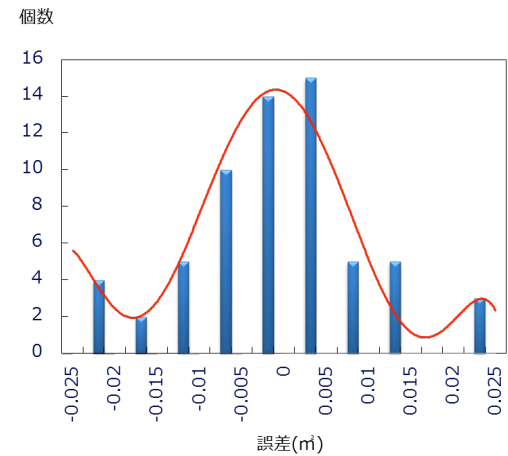

図-16 測定精度比較結果

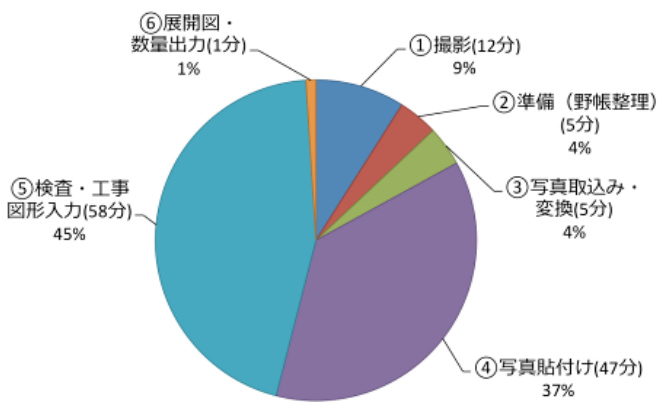

図-17 本システム作業時間の工程別割合

\section{参考文献}

1) Godfried Augenbroe :Integrated Building Design Systems in Context of Product Data Technology, Journal of Computing in Civil Engineering, Vol/8, No.4, pp.420-435, 1994.

2) 元永秀 : CIM が目指寸理想を実現するために, http://committees.jsce.or.jp/cceips07/system/files/CIM02_motonaga. pdf，(入手 2013.06.20).

3）国土交通省 : CIM の導入検討について, http://www.mlit.go.jp/common/000221538.pdf，(入手 2013.06.20).

4) $\mathrm{CIM}$ 技術検討会 : CIM 技術検討報告会 平成 24 年度報告, http://www.cals.jacic.or.jp/CIM/Contents/CIM_Report130430.pdf, (入手 2012.06.20)

5）情報化施工推進会議 : 情報化施工推進戦略, http://www.mlit.go.jp/common/000991631.pdf，(入手 2013.06.20).

6) Behzad Abbasnejad, Hashem Izadi Moud : BIM and Basic Challenges Associated with its Definitions, Interpretations and Expectations, International Journal of Engineering Research and Applications (IJERA) ISSN: 2248-9622 www.ijera.com Vol. 3, Issue 2, pp.287-294, 2013.

7) 小林一郎,池本大輔,竹下史朗,坂口将人 : 3D-CAD を基盤とし たトータルデザインシステムの提案，土木情報利用技術論文 集,Vol.17,pp.171-182,2008.

8) 小林一郎,島津卓郎,増山晃太,宮崎浩三:河川堤防設計における CIM の可能性,土木情報学シンポジウム講演集,Vol. 38, 2013.

9）国土交通省 : 鉄道構造物の維持管理に関する基準の検証会議 について,

https://www.mlit.go.jp/common/000995186.pdf, (入手 2013.04.25).

10) 例えば鉄道構造物等維持管理標準・同解説（構造物編 コン クリート構造物) .

11）鈴木秀門, 木村元哉, 御㟝哲一, 中山忠雅 : RC 高架橋 のコンクリート劣化に対応した橋梁保守管理システム の構築，土木学会第 58 回年次学術講演会, IV-087, 2003. 
Development of Bridge Management System using Three-Dimensional Model

\section{Tomohiro SHIMIZU, Shin YOSHIKAWA, Hideyuki Takinami, Norikazu MISAKI, Yasumasa TAKAHASHI, Tadamasa NAKAYAMA, Osamu UCHIDA and Kenichi KONDO}

It is necessary to manage various data in order for maintaining bridge structures appropriately. In the usual maintenance management of the West Japan Railway, inspection and repair are carried out by referring to 2D drawings (extended elevation). However, the following problems exist. The first problem is that the $2 \mathrm{D}$ drawings (extended elevations) are only a schematic illustration without dimensions. The second is that those drawing are not shared in both repair and inspection. The third is that it is difficult to grasp in chronological order based on those 2D drawings.In this study, the authors developed a maintenance management system by using 3D bridge models. Also, the authors developed system that can easily make the 2D drawings (extended elevations) for management of the inspections and repairs. In addition, the validity of this system was confirmed by comparing with the conventional method. 